\section{EFFECT OF EXERCISE ON INSULIN RESISTANCE IN OBESE TYPE 2 DIABETES PATIENTS}

\author{
EFEITO DO EXERCÍCIO SOBREA RESISTÊNCIA ÀINSULINA EM PACIENTES OBESOS COM DIABETES TIPO 2
}

EFECTO DEL EJERCICIO SOBRE LA RESISTENCIA A LA INSULINA EN PACIENTES OBESOS CONDIABETES TIPO 2

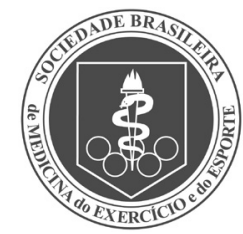

Original Article Artigo OrigINAL Artículo Original

\section{Bin Zhang 1 (ID \\ (Physical Education Professional) \\ 1. Ulanqab Medical College, Wulanchabu City, Inner Mongolia, China.}

\section{Correspondence:}

Bin Zhang

Wulanchabu City, Inner

Mongolia, China. 012000

zhangbin19850214@163.com

\begin{abstract}
Introduction:Type 2 diabetes mellitus (T2DM), also known as non-insulin-dependent diabetes mellitus (NIDDM), accounts for more than $90 \%$ of the total number of diabetes mellitus cases and often occurs in middle-aged and elderly people. Objective: To investigate the effect of exercise intervention on insulin resistance in obese type 2 diabetes patients. Methods: Eighty-six obese diabetic patients were screened as experimental subjects in physical examinations and randomly divided into observation and control groups. Visceral fat volume, fasting blood glucose, and fasting insulin of all subjects were measured before and after completion of the 6-month experimental implementation. The insulin resistance was calculated for both groups and the values for each indicator were compared statistically between groups. Results: Control of body weight, body mass index, blood glucose, blood lipids and insulin resistance index were better in the observation group than in the control group, and the difference was statistically significant $(P<0.05)$. Conclusions: Basal intervention with quantitative exercise can significantly improve insulin resistance in obese type 2 diabetes patients and the effect is better than treatment with diet and conventional exercise. Level of evidence ll; Therapeutic studies - investigation of treatment results.
\end{abstract}

Keywords: Insulinum; Sports; Diabetes Mellitus Complication.

\section{RESUMO}

Introdução: O diabetes mellitus tipo 2(T2DM), também conhecido como diabetes mellitus não insulino-dependente (NIDDM), é responsável por mais de 90\% do total de casos de diabetes mellitus e, com frequência ocorre em pessoas de meia-idade e idosos. Objetivo: Investigar o efeito da intervenção com exercícios sobre a resistência à insulina em pacientes obesos com diabetes tipo 2. Métodos: Oitenta e seis pacientes diabéticos obesos foram selecionados como participantes experimentais em exames físicos e foram divididos randomicamente em grupos de observação e controle. Gordura visceral, glicose e insulina sanguíneas em jejum de todos os individuos foram medidas antes e depois do término do experimento de seis meses. A resistência à insulina foi calculada para ambos os grupos e os valores de cada indicador foram comparados estatisticamente entre os grupos. Resultados: O controle de peso, índice de massa corporal, glicose e lipides sanguíneos e o índice de resistência à insulina foram melhores no grupo observação do que no grupo controle, e a diferença foi estatisticamente significativa $(P<0,05)$. Conclusões: A intervenção basal com exercícios quantitativos pode melhorar significativamente a resistência à insulina em pacientes obesos com diabetes tipo 2 e seu efeito é melhor do que a dieta e a terapia com exercícios convencionais. Nível de Evidência ll; Estudos terapêuticos - Investigação dos resultados do tratamento.

Descritores: Insulinum; Esportes; Complicações do diabetes.

\section{RESUMEN}

Introducción: La diabetes mellitus tipo 2 (DMT2), también conocida como diabetes mellitus no insulinodependiente (DMNID), representa más del $90 \%$ de todos los casos de diabetes mellitus y suele afectar a personas de mediana edad y ancianos. Objetivo: Investigar el efecto de la intervención con ejercicios sobre la resistencia a la insulina en pacientes obesos con diabetes tipo 2. Métodos: Se seleccionaron 86 pacientes diabéticos obesos como participantes experimentales en exámenes físicos y se dividieron aleatoriamente en grupos de observación y control. Se midieron la grasa visceral, la glucosa y la insulina en ayunas de todos los individuos antes y después de finalizar el experimento de seis meses. Se calculó la resistencia a la insulina en ambos grupos y se compararon estadísticamente los valores de cada indicador entre los grupos. Resultados: El control del peso, el índice de masa corporal, la glucosa y los lípidos en la sangre y el índice de resistencia a la insulina fueron mejores en el grupo de observación que en el grupo de control, y la diferencia fue estadísticamente significativa $(P<0,05)$. Conclusiones: La intervención inicial con ejercicios cuantitativos puede mejorar significativamente la resistencia a la insulina en pacientes obesos con diabetes tipo 2 y su efecto es mejor que la dieta y la terapia con ejercicios convencionales. Nivel de Evidencia II; Estudios terapéuticos - Investigación de los resultados del tratamiento.

Descriptores: Insulinum; Deportes; Complicaciones de la diabetes. 


\section{INTRODUCTION}

According to the data of the World Health Organization (WHO), there are about 180 million diabetes patients in the world at present, and it is predicted that the number will rise to 360 million in 2030, and about 2.9 million people die of diabetes every year. ${ }^{1}$ According to WHO etiological classification in 1997, type 2 diabetes mellitus (T2DM), also known as non-insulin-dependent diabetes mellitus (NIDDM), accounts for more than $90 \%$ of the total number of diabetes mellitus and often occurs in middle-aged and elderly people. ${ }^{2}$ It is generally believed that the risk factors of diabetes are closely related to obesity, especially visceral obesity. ${ }^{3}$ The prevalence of obesity is increasing year by year. Studies have shown that obese patients have increased risk factors for diabetes, cardiovascular disease, abnormal lipid metabolism and other metabolic diseases, which has become a global problem endangering human health. Obesity and type 2 diabetes mellitus often co-exist, often manifested by insulin resistance (IR), decreased glucose tolerance. ${ }^{4}$ How to reduce the weight of obese diabetic patients to the ideal weight is the key to improve disease control and metabolic indicators. ${ }^{5}$ Barchetta l's study examined the effect of weight loss on insulin resistance and the dysregulation of adhesion molecules and adipokines in obese type 2 diabetes patients. ${ }^{6}$

\section{METHOD}

\section{Clinical data}

Obese patients with type 2 diabetes who visited the endocrinology Clinic of our hospital from June 2019 to August 2020 were selected. Inclusion criteria: 1) Type 2 diabetes, conforming to the WHO diabetes standard in 1999; 2) Obesity, in accordance with the standards of obesity in 2003 "guidelines for overweight and obesity prevention and control in Chinese adults (trial)", that is, bodymassindex (BMI) $\geq 28 \mathrm{~kg} / \mathrm{m} 2$ is obe$\mathrm{se}^{.7-8} 3$ ) Have basic reading and writing skills; 4) No serious myocardial ischemia, severe hypertension and other exercise contraindications; 5) No other endocrine diseases; 6) The condition is stable recently, and the hypoglycemic drugs used are insulin secreting agents and/or glycosidase inhibitors. There were 52 males and 34 females, aged from 27 to 62 years, with an average age of ( $48.71 \pm 9.66)$ years. There was no statistically significant difference in the general data of age and gender between the two groups $(P>0.05)$, indicating comparability. ${ }^{9}$

\section{Research Methods}

On the basis of the original hypoglycemic drug treatment, the two groups of patients were guided by centralized teaching, food demonstration, telephone follow-up and other forms for 6 months.

1. The control group was given routine diabetic diet guidance and exercise intervention

Routine diabetes dietary guidance: the content includes balanced diet and nutrition, and the total daily energy required is calculated according to the age, height, weight, body mass index and labor intensity of each patient, the total number of food exchanges per day was estimated and proportionally divided into 3 meals and 6 food groups, foods that should be avoided or abstained and dietary precautions were indicated. ${ }^{10}$
2. The observation group was given quantitative exercise intervention based on glycemic load on the basis of the control group

Routine dietary guidance for diabetes: The contents included balanced diet and nutrition, and the total daily energy requirements were calculated according to the age, height, weight, body mass index, labor intensity, etc., of each patient, and the total exchange of food intake per day was estimated, the food was divided into 3 meals and 6 kinds of food in proportion, and the food which should be avoided or forbidden and dietary precautions were pointed out.

\section{Observation Indicators}

Before the experiment, height, weight, BMI, waist circumference, hip circumference, fasting blood glucose (FBG), 2hpostpran dialplasma glucose (2h postprandial plasma glucose) were improved in all patients. Hemoglo bin A1c (HbA1c), total cholesterol (TC), Triglyceride (TG), low density lipoproteincholesterol, Ldl-c, high density lipoproteincholesterol (hdl-c), fasting insulin (FINS) and other indicators. During the follow-up period, the above indicators were examined once every 3 months. Home ostatic model assessment of insulin resistance $(\mathrm{HOMAIR})=(\mathrm{FBG} \times \mathrm{FINS})$ /22.5 was calculated using homeostasis model.

\section{Statistical Methods}

SPSS13.0 statistical software was used, the measurement data was expressed as $x \pm s$, and $t$ test was used. $P<0.05$ was considered statistically significant.

\section{RESULTS}

Changes of body weight, BMI, waist circumference and hip circumference in 2 groups before and after treatment

Before treatment, there were no significant differences in body weight, BMI, waist circumference and hip circumference between 2 groups ( $P>0.05)$. After 6 months of treatment, the above indexes in 2 groups decreased compared with before, but the observation group decreased significantly, the difference was statistically significant $(P<$ 0.05). (Table 1)

\section{Changes of FBG, 2hPBG, HbA1c, FINS and HOMA-IR in 2 groups before and after treatment}

Before treatment, there were no significant differences in FBG, $2 \mathrm{hPBG}$, HbA1C, FINS and HOMA-IR between 2 groups $(P>0.05)$. After 6 months of treatment, the above indexes in 2 groups decreased compared with before, but the observation group decreased significantly, the difference was statistically significant $(P<0.05)$. (Figure 1 and Table 2)

\section{Changes of TC, TG, LDL-C and HDL-C in 2 groups before and after treatment}

There was no significant difference in blood lipid between the two groups before treatment $(P>0.05)$. After 6 months of treatment, hdL-C level in both groups increased compared with before, but significantly increased in observation group, the difference was statistically significant $(P<0.05), T G, T C$ and LDL-C in both groups decreased compared with before, but significantly decreased in the observation group, with statistical significance $(P<0.05)$. (Table 3$)$

Table 1. Changes of body weight, BMl, waist circumference and hip circumference in the two groups before and after treatment.

\begin{tabular}{|c|c|c|c|c|c|c|c|c|c|}
\hline \multirow[b]{2}{*}{ Group } & \multirow[b]{2}{*}{$\mathrm{n}$} & \multicolumn{2}{|c|}{ Weight } & \multicolumn{2}{|c|}{ BMI } & \multicolumn{2}{|c|}{ Waist circumference } & \multicolumn{2}{|c|}{ Hip circumference } \\
\hline & & $\begin{array}{l}\text { Before the } \\
\text { treatment }\end{array}$ & After treatment & $\begin{array}{l}\text { Before the } \\
\text { treatment }\end{array}$ & After treatment & $\begin{array}{l}\text { Before the } \\
\text { treatment }\end{array}$ & After treatment & $\begin{array}{l}\text { Before the } \\
\text { treatment }\end{array}$ & After treatment \\
\hline The control group & 43 & $83 \pm 12$ & $78 \pm 11$ & $30 \pm 2$ & $28 \pm 2$ & $104 \pm 7$ & $100 \pm 6$ & $110 \pm 7$ & $107 \pm 6$ \\
\hline Observation group & 43 & $811 \pm 0$ & $73 \pm 9$ & $30 \pm 1$ & $27 \pm 1$ & $103 \pm 7$ & $95 \pm 5$ & $109 \pm 7$ & $104 \pm 4$ \\
\hline
\end{tabular}


Table 2. Changes of FBG, 2 h PBG, HbA1c, FINS and HOMA-IR in the two groups before and after treatment.

\begin{tabular}{c|c|c|c}
\hline Group & & The control group & Observation group \\
\hline $\mathbf{n}$ & & $\mathbf{4 3}$ & $\mathbf{4 3}$ \\
\hline \multirow{2}{*}{ FPG } & Before the treatment & $9 \pm 2$ & $9 \pm 3$ \\
\cline { 2 - 4 } & After treatment & $6 \pm 1$ & $5 \pm 1$ \\
\hline \multirow{2}{*}{$2 \mathrm{hPBG}$} & Before the treatment & $13 \pm 3$ & $13 \pm 3$ \\
\cline { 2 - 4 } & After treatment & $8 \pm 4$ & $8 \pm 1$ \\
\hline \multirow{2}{*}{ HbA1C } & Before the treatment & $8 \pm 4$ & $9 \pm 6$ \\
\cline { 2 - 4 } & After treatment & $7 \pm 1$ & $6 \pm 1$ \\
\hline \multirow{2}{*}{ FINS } & Before the treatment & $12 \pm 4$ & $12 \pm 4$ \\
\cline { 2 - 4 } & After treatment & $11 \pm 3$ & $9 \pm 3$ \\
\hline \multirow{2}{*}{ HOMA-IR } & Before the treatment & $5 \pm 2$ & $5 \pm 2$ \\
\cline { 2 - 4 } & After treatment & $3 \pm 1$ & $2 \pm 1$ \\
\hline
\end{tabular}



Figure 1. Changes of FBG, 2 h PBG, HbA1c, FINS and HOMA-IR in the two groups before and after treatment.

Table 3. Changes of TC, TG, LDL-C and HDL-C in the two groups before and after treatment.

\begin{tabular}{|c|c|c|c|c|c|c|c|c|c|}
\hline \multirow[b]{2}{*}{ Group } & \multirow[b]{2}{*}{$\mathrm{n}$} & \multicolumn{2}{|c|}{$\mathrm{TC}$} & \multicolumn{2}{|c|}{ TG } & \multicolumn{2}{|c|}{ LDL-C } & \multicolumn{2}{|c|}{ HDL-C } \\
\hline & & $\begin{array}{l}\text { Before the } \\
\text { treatment }\end{array}$ & After treatment & $\begin{array}{l}\text { Before the } \\
\text { treatment }\end{array}$ & After treatment & $\begin{array}{l}\text { Before the } \\
\text { treatment }\end{array}$ & After treatment & $\begin{array}{l}\text { Before the } \\
\text { treatment }\end{array}$ & After treatment \\
\hline The control group & 43 & $5 \pm 1$ & $5 \pm 1$ & $3 \pm 2$ & $2 \pm 2$ & $4 \pm 1$ & $3 \pm 1$ & $1 \pm 1$ & $1 \pm 1$ \\
\hline
\end{tabular}

\section{DISCUSSION}

Exercise therapy is one of the five cornerstones of T2DM treatment. As a non-drug method, exercise has been paid more and more attention for its advantages of convenience, economy, good curative effect and good influence on other systems of the body. In addition, exercise therapy has obvious advantages in the prevention of T2DM. A large number of data show that T2DM is highly correlated with obesity, lack of exercise and other factors, and regular aerobic exercise has a significant effect on the prevention and treatment of T2DM. The results of this study showed that VFA, FPG, FINS and HOMA-IR indexes in exercise group were significantly decreased after aerobic exercise intervention for 6 months compared with control group or before and after the experiment $(P<0.01)$. The results showed that aerobic exercise in this study had a significant effect on reducing visceral fat in middle-aged and elderly obese T2DM patients. It also indicates that aerobic exercise intervention can reduce blood glucose, insulin and insulin resistance index in middle-aged and elderly obese T2DM patients, alleviate hyperglycemia, reduce insulin resistance, and enhance the sensitivity of tissue cells to insulin. This study confirmed that aerobic exercise intervention can effectively reduce VFA index in middle-aged and elderly obese T2DM patients, however, the subjects of this study were middle-aged and elderly obese T2DM patients, whether the above effects of aerobic exercise intervention can have similar effects on other age groups of T2DM patients or middle-aged and elderly obese non-T2DM patients, especially those at high risk of T2DM with impaired glucose tolerance (IGT), needs further study.

\section{CONCLUSION}

Clinical practice shows that the effect of traditional and single treatment for diabetes patients is not satisfactory, so comprehensive treatment measures should be taken to provide specific guidance in nutrition, exercise therapy and other aspects of patients, in order to better control the disease, reduce and eliminate complications. In this study, it was found that insulin resistance and blood glucose and lipid levels of obese type 2 diabetes patients were significantly improved through quantitative exercise intervention, which was better than conventional diet and exercise treatment.

\section{ACKNOWLEDGMENT}

The topic of autonomous regional planning project: A Practical Research on the Influence of the Talent Training Mode of Combining Sports and Medicine on Healthy China in Medical Colleges. Subject number: NGJ GH2020459.

The author declare no potential conflict of interest related to this article

\section{REFERENCES}

1. Tai $H$, Wang MY, Zhao YP, Li LB, Dong QY, Liu XG, et al. The effect of alogliptin on pulmonary function in obese patients with type 2 diabetes inadequately controlled by metformin monotherapy. Medicine. 2016;95(33):e4541.

2. Qin J, Zhao K, Y Chen, Guo S, You Y, Xie J, et al. The Effects of Exercise Interventions on Balance Capacity in Patients with Type 2 Diabetes Mellitus: A Systematic Review and Meta-Analysis. Inquiry. 2021;58(4):004695802110182.

3. Kim SW, Jung WS, Chung S, Park HY. Exercise intervention under hypoxic condition as a new therapeutic paradigm for type 2 diabetes mellitus: A narrative review. World J Diabetes. 2021;12(4):331-43.

4. Liu JF, Song WJ. Effect of exercise and dietary intervention on lipid metabolism, insulin sensitivity and microinflammatory state in obese children. J Hainan Med. 2017;23(016):78-81.

5. Barchetta I, Ben MD, F Angelico, Di Martino M, Fraioli A, La Torre Get al. No effects of oral vitamin D supplementation on non-alcoholic fatty liver disease in patients with type 2 diabetes: a randomized, double-blind, placebo-controlled trial. BMC Med. 2016;14(1):92.
6. Zou Z, Wei C, Min C, Xiao M, Wang Z. Influence of the intervention of exercise on obese type Il diabetes mellitus: A meta-analysis. Prim Care Diabetes. 2016;10(3):186-201.

7. Jiang $X$, Fan $X$, Wu R, Geng F, Hu C. The effect of care intervention for obese patients with type II diabetes. Medicine. 2017;96(42):e7524

8. Aldekhail NM, Logue J, Mcloone P, Morrison DS. Effect of orlistat on glycaemic control in overweight and obese patients with type 2 diabetes mellitus: a systematic review and meta-analysis of randomized controlled trials. Obes Rev. 2016;16(12):1071-80.

9. Baltzis D, Grammatikopoulou MG, Papanas N, Trakatelli CM, Kintiraki E, Hassapidou MN, et al. Obese Patients with Type 2 Diabetes on Conventional Versus Intensive Insulin Therapy: Efficacy of Low-Calorie Dietary Intervention. Adv Ther. 2016;33(3):447-59.

10. Motkova SI, Savelyeva LV, Rudina LM, Gurkina MV, Surkova E, Valeeva FV, et al. Multidisciplinary lifestyle management approach in patients with type 2 diabetes mellitus in real clinical practice. Results of application "Life is easy" programme in Russia. Diabetes Mellitus. 2019;22(2):115-26. 